\title{
Okul Öncesi Eğitim Paydaşlarının Çocuk Haklarına İlişkin Tutumlarının İncelenmesi
}

\author{
Ayhan BULUT ${ }^{1}$
}

\section{$\ddot{\mathrm{O} z}$}

$\mathrm{Bu}$ araştırmanın amacı; okul öncesi öğretmen adaylarının, okul öncesi öğretmenlerinin ve şu anda okul öncesi eğitimde öğrencisi bulunan velilerin çocuk haklarına ilişkin tutumlarını tespit etmek ve varsa çocuk haklarına ilişkin tutumları arasındaki farklılığı ortaya çıkarmaktır. Bu araştırmada nicel araştırmaya dayalı tarama modelinde tasarlanmıştır. Araştırma verileri 2019-2020 eğitim öğretim yllı bahar döneminde eğitim kurumlarının yüz yüze eğitime devam ettiği süreçte toplanmıştır. Bu süreçte Erzurum ili merkez ilçelerinde okul öncesi eğitim kurumlarında görev yapan 71 okul öncesi öğretmeni, Bayburt Üniversitesinde ve Tokat Gazi Osmanpaşa Üniversitesi okul öncesi öğretmenliği lisans eğitimi alan 97 okul öncesi öğretmen adayı oluşturmuştur. Ayrıca Erzurum, İstanbul, İzmir, Ankara, Adana, Malatya ve Erzincan illerinde çocukları okul öncesi eğitim kurumlarına gönderen 245 veli araştırmanın örneklem grubunda yer almışlardır. Araştırmada veri toplama aracı olarak araştırmacının kendisi tarafından geliştirilen "Demografik Bilgi Toplama Formu” ile Karaman-Kepenekçi (2006) tarafindan geliştirilen "Çocuk Haklarına İlişkin Tutum Ölçeği” kullanılmıştır. Araştırmadan elde edilen diğer bir sonuca göre okul öncesi öğretmen adaylarının, okul öncesi öğretmenlerinin ve velilerin çocuk haklarına ilişkin tutum ölçeğinden aldıkları (ÇHTÖ) puanların ortalamaları arasında anlamlı fark olduğu belirlenmiştir.

Anabtar Kelimeler: Okul Öncesi, Öğretmen Adayı, Okul Öncesi Öğretmenleri, Veli, Çocuk Hakları, Tutum

\section{Investigation of Pre-School Education Stakeholders' Attitudes towards Children's Rights}

\begin{abstract}
The purpose of this research; To determine the attitudes of pre-school teacher candidates, preschool teachers and parents who are currently enrolled in pre-school education towards children's rights and to reveal the difference between their attitudes towards children's rights, if any. This study was designed as a survey model based on quantitative research. The research data were collected in the spring term of the 2019-2020 school year when education was given face to face. The sample group of this study consisted of 71 preschool teachers, working in the central districts of the province of Erzurum, 97 preschool teacher candidates receiving undergraduate education in the departments of preschool teaching at Bayburt University and Tokat Gazi Osmanpasa University. In addition, 245 parents, whose children were enrolled in pre-school education institutions in the provinces of Erzurum, Istanbul, Izmir, Ankara, Adana, Malatya and Erzincan were also included in the sample group. In this study, "Demographic Information Collection Form" developed by the researcher and "Attitude Scale for Children's Rights" developed by Karaman Kepenekci (2006) were used as data collection tools. It was found out according to the results of this research there was a significant difference among the mean scores received by preschool teacher candidates, preschool teachers and parents from the attitude scale for children's rights (CHTO).
\end{abstract}

Key Words: Preschool, Pre-service Teacher, Preschool Teachers, Parent, Child Rights, Attitude

Attf İçin / Please Cite As:

Bulut, A. (2020). Okul Öncesi Eğitim Paydaşlarının Çocuk Haklarına İlişkin Tutumlarının İncelenmesi. Manas Sosyal Arasttrmalar Dergisi, 9(4), 2067-2078.

Geliş Tarihi / Received Date: 21.04.2020

Kabul Tarihi / Accepted Date: 13.07.2020

\footnotetext{
${ }^{1}$ Dr. Öğr. Üyesi - Bayburt Üniversitesi, Bayburt Eğitim Fakültesi, Okul Öncesi Eğitimi Ana Bilim Dalı, ayhanbulut4480@gmail.com - ORCID: 0000-0001-6482-8032
} 


\section{Giriş}

Batı'da 16. yüzyıldan itibaren başlayan çocukluk kavramına yönelik fikirler, 17. yüzyılla birlikte kendini giderek gündelik ve somut yaşantıların içerisinde göstermeye başlamış, çocuğun masumiyeti ve zayıflı̆̆ına dikkat çekilmiştir (Taşkın, 2006, s. 38-45). İkinci dünya savaşının çocuklar üzerinde olumsuz etkisi ve çocukların bu savaş sürecinde yaşadığı zorlu koşulların birçok Avrupa ülkelerinde görülmesi başta bu Avrupa ülkeleri olmak üzere birçok dünya ülkelerinin bu konuda daha duyarlı olmaya sevk etmiştir (Hamon, 2006, s. 51-78). Bu ilgi çocuğa yönelik bakış açısını tüm dünyada değiştirerek çocuk kavramının ve çocuğun gelişimsel özelliklerini göz önünde bulundurarak tekrardan betimlemeye olanak tanımıştır. Bilimsel ve ekonomik alandaki gelişmeler, insan haklarına yönelik yapılan çalışmalar, çocuğa ait var olan bütün tanımlamaları yeniden şekillendirmiş ve 20. yüzyılı, "Çocuk Yüzyllı" olarak karşımıza çıkarmıştır (Gander ve Gardiner, 2010 Akt: Sağlam ve Aral, 2016, s. 43-56). Tüm dünyada çocuklar içinde bulundukları gelişim özellikleri ve dönemleri açısından korunmaya ve bakıma ihtiyaç duyan varlıklardır.

Yaşam boyu öğrenme özelliğine sahip olan insan hayatının her döneminde bilişsel, zihinsel, psikomotor, dil gelişimi ve sosyokültürel açıdan gelişimini devam ettirir. Bireyin gelişim dönemlerinin içerisinde en hızlı ögrendiği ve gelişimlerini devam ettirdiği dönem 0-6 yaş arası arasında kalan erken çocukluk dönemidir. Geçmişte çocuğa karşı var olan yetişmemiş birey algisı (Hart ve Pavlovic, 1991, s. 345-358) günümüzde değişmiş ve çocuk artık kendine özgü ihtiyaçlarına ve hakları olan, korunması gereken bir varlık olarak görülmeye başlanmıştır (Archard, 1993, s. 32; Alderson, 2000, s. 70; Franklin, 2001, s. 210).

Çocuklar, tüm insanların sahip olduğu haklarla birlikte, gelişim özelikleri sebebiyle birtakım özel haklara da sahiptirler. Çocuk hakları, çocuğun hem insan olmasından, hem de bakıma ve korunmaya ihtiyaç duymasından kaynaklanan haklardır. Genel anlamda, çocukların bedensel, zihinsel, duygusal ve sosyal olarak gelişebilmesi için hukuk kuralları ile korunan yararları olarak tanımlanabilir (KaramanKepenekçi, 2008). Çocuk Hakları Sözleşmesi çocukların tüm yönleriyle gelişimlerine yanıt verebilmek amacıyla, Birleşmiş Milletler Genel Kurulu tarafindan 20 Kasım 1989 tarihinde kabul edilerek 2 Eylül 1990 tarihinde yürürlüğe giren çocuklara ilişkin ilk uluslararası sözleşmedir. Çocuk hakları sözleşmesi aralarında Türkiye'nde olduğu yaklaşık 142 ülke sözleşmeyi imzalamış ya da onay ve katılma yoluyla taraf devlet durumuna gelmiştir. Türkiye'de Çocuk Hakları Sözleşmesi'ni 2 Ekim 1995’ten beri yürürlüğe girmiştir. Çocuk Hakları Sözleşmesi ile çocuğun, yaşama, barınma, eğitim, güvenlik, isim hakkı, vatandaşlık, hak ve özgürlükleri, kimlik, kimliğinin korunması, düşünce, vicdan hakk1, inanç özgürlüğü, dernek kurma, özel yaşam dokunulmazlı̆̆1, işkenceden korunma, kötü muamele görmeme, cezalandırılmama gibi hakları koruma altına alınmaktadır (Karaman-Kepenekci ve Baydık, 2009). Sözleşme ayrım gözetmeme, her konuda çocuğun yüksek yararının düşünülmesi, yaşam, gelişme ve katılım haklarını temel almakla birlikte, cinsiyeti, doğum yeri, dini, ailesi veya toplumsal kökeni ne olursa olsun 18 yaşindan küçük bütün kişilerin haklarını kapsamaktadır (Cilga, 2001, s. 69-73).

Modern çağda her toplum; kendi haklarını bilen ve birbirlerinin haklarına saygı duyan bireyler yetiştirmeyi öncelikli amaç haline getirmişlerdir. Okul öncesi eğitimde çocuklar arasında herhangi bir nedenle ayrım gözetmeksizin onların haklarına yönelik olarak gösterilecek hassasiyet ve dikkat güçlü bir toplum inşası için büyük bir adım olabilir. Okul öncesi eğitim sürecinin doğrudan yer alan eğitim paydaşlarının öğretmen, aday öğretmen ve okul öncesi velilerinin çocuk haklarına ilişkin tutumlarının belirlenmesi ve okul öncesi eğitimin içerisinde yer alan eğitim paydaşlarının çocuk haklarına ilişkin tutumlarının karşılaştırılması önemli görülmektedir. Çocuk doğduğu günden itibaren ilk eğitimini aileden, daha sonra ailenin isteği doğrultusunda örgün eğitimle ilk defa karşılaştı̆̆ okul öncesi eğitim kurumlarında almaktadır. Ailede ve okulda çocukların haklarını öğrenmesine ve kullanmasına izin verildiğinde kendini ilgilendiren kararlara ve işlere katılma hakkı tanındığında, kendi davranışlarını denetleme yeterliliği kazandırıldığında demokrasi eğitiminin amaçları da gerçekleştirilmiş olur (Başaran, 2005). Okul öncesi eğitim kurumlarına devam eden öğrencilerin tüm zamanları evde ve okulda geçirdikleri düşünüldüğünde başta ailelerin, sonrasında okul öncesi öğretmenlerinin ve daha sonrasında okul öncesi öğretmen adaylarının çocuk hakları konusunda gerekli bilgi birikimine sahip olması ve konuyla ilgili yeterli farkındalı̆ga sahip olarak eğitim sürecinde yer alması konuyla ilgili niteliği arttıracaktır.

Çocuk hakları eğitimine yönelik sorunların temelinde, yetişkinlerin çocukların haklarını tanımaması ve öğretmen yetiştirme sürecinde konuyla ilgili ihtiyaçların karşılanmamasıdır (Covell, Howe ve McNeil, 2010, s. 117-132). Çocuk haklarının korunmasında, öğretmenlerin okullardaki en hassas kişiler olması beklendiğinden meslek yaşamları öncesinde, öğretmenlik lisans programlarında çocuk haklarına ilişkin 
derslerin yer almasının ya da konu ile ilgili farklı derslerin içerik olarak çocuk hakları temasını da içerecek şekilde zenginleştirilmesi gerekliliği (Hareket, 2019, s. 167-180; Dağl1, 2015, s. 231; Karaman-Kepenekci ve Baydık, 2009, s. 329-350) ifade edilmiştir.

İlgili alan yazın incelendiğinde Türkiye'de okulöncesi dönemde çocuk haklarına yönelik yapılan araştırmalara bakıldığında ebeveynlerin, öğretmenlerin ve öğretmen adaylarının çocuk haklarına ilişkin tutumlarını incelemeye yönelik (Tüysüzer, 2018, s. 1-129; Dinç, 2015, s. 7-25; Doğan, Torun ve Akgün, 2014, s. 503-516; Kor, 2013; Washington, 2010, s. 1-215; Yurtsever, 2009, s. 1-250) çalısmaların bulunduğu tespit edilmiştir. Görüldüğü gibi ilgili literatür incelendiğinde öğretmenlerin, öğretmen adaylarının, ailelerin ve okul yöneticilerinin çocuk haklarına karşı tutumlarını ayrı ayrı inceleyen alanda yapılmış çalışmalara rastlamak mümkündür. Bununla birlikte bu araştırma üzerinde çalışılan örneklem gruplarının, okul öncesi ögrretmen adayları, okul öncesi öğretmenleri ve okul öncesi eğitimde öğrencisi bulunan velilerin çocuk haklarına ilişkin tutumlarını bir arada incelemesi ortaya çıkan mevcut durumları karşılaştırması açısından bir ilk olması açısından da önemlidir. Türkiye'de bu kapsamda okul öncesi eğitimle ilgili paydaşların çocuk haklarına yönelik tutumlarına ilişkin konuyla ilgili kişilere bir vizyon çizeceği ve yol haritası olacağı düşüncesiyle de önemli görülmektedir. Ayrıca toplumda çocuk haklarına ilişkin farkındalık düzeyini artıracağı ve geliştireceği düşünülmektedir.

$\mathrm{Bu}$ araştırmanın amacı; okul öncesi öğretmen adaylarının, okul öncesi öğretmenlerinin ve şu anda okul öncesi eğitimde öğrencisi bulunan velilerin çocuk haklarına ilişkin tutumlarını tespit etmek ve varsa çocuk haklarına ilişkin tutumları arasındaki farklılı̆ı ortaya çıkarmaktır. Bu amaç doğrultusunda aşağıdaki sorulara cevap aranmıştır:

1. Araştırmanın örneklem grubunda yer alan okul öncesi öğretmen adayı, okul öncesi öğretmeni ve okul öncesi eğitime şu anda devam çocuğu olan velilerin yaş, cinsiyet ve eğitim durumlarına ilişkin özelikleri nelerdir?

2. Okul öncesi öğretmen adaylarının, öğretmenlerin ve velilerin çocuk haklarına ilişkin tutum ölçeğinden aldıkları puanları arasında fark var mı?

3. Okul öncesi öğretmen adaylarının, öğretmenlerin ve velilerin yaşlarına göre çocuk haklarına ilişkin tutum ölçeğinden aldıkları puanlar arasında fark var mıdır?

4. Okul öncesi öğretmen adaylarının, öğretmenlerin ve velilerin cinsiyetlerine göre çocuk haklarına ilişskin tutum ölçeğinden aldıkları puanlar arasında fark var mıdır?

5. Okul öncesi öğretmen adaylarının, öğretmenlerinin ve velilerin eğitim durumlarına göre çocuk haklarına ilişkin tutum ölçeğinden aldıkları puanlar arasında fark var mıdır?

\section{Yöntem}

$\mathrm{Bu}$ araştırmada nicel araştırmaya dayalı tarama modelinde tasarlanmıştır. Tarama modelleri sosyal bilimlerde yaygın olarak kullanılan ve büyük gruplar üzerinde çalışma olanağı veren tarama çalışmaları, araştırmacının bağımsız değişken ya da faktörler üzerinde manipülasyonunun olmadığı (Büyüköztürk, 2014, s. 19) geçmişte ya da hâlen var olan bir durumun var olduğu şekliyle betimlenmesini amaçlayan araştırmalardır (Karasar, 2012).

\section{Evren - Örneklem}

Araştırmanın evrenini resmi eğitim kurumlarında görev yapan okul öncesi öğretmenleri, üniversitelerde lisans düzeyinde okul öncesi öğretmenliği eğitimi alan aday öğretmenler ve şu anda okul öncesi eğitim düzeyinde çocuğu bulunan veliler oluşturmaktadır.

Evren çok geniş olduğundan dolayı evrenden kolay ulaşılabilir örnekleme yöntemiyle rastgele olarak örneklem alma yoluna gidilmiştir. Kolay ulaşılabilir veya elverişli örnekleme tamamen mevcut olan, ulaşması hızlı ve kolay olan öğelere dayanır. Sosyal bilimlerde en yaygın kullanılan örnekleme türlerinden biri uygun örneklemedir. Uygun örneklemede, araştırmacılar katılımcıları ulaşması kolay, araştırma için uygun ve gönüllü bireylerden seçmektedir (Gravetter ve Forzano, 2012, s. 43). Kısaca uygun örnekleme, araştırmacı için uygun örneklemin seçilmesidir. Araştırma verileri 2019-2020 eğitim öğretim yılı bahar döneminde eğitim kurumlarının yüz yüze eğitime devam ettiği süreçte toplanmıştır. Bu kapsamda araştırmacı tarafindan ulaşılması kolay ve araştırmaya gönüllü olarak destek vermek isteyen; Erzurum ili merkez ilçelerinde okul öncesi eğitim kurumlarında görev yapan 71 okul öncesi öğretmeni ile Bayburt Üniversitesi okul öncesi öğretmenliği lisans programında şu anda 1. sinıfa devam eden 43 okul öncesi öğretmen adayı ile Tokat Gazi Osmanpaşa üniversitesi okul öncesi eğitimi programında şu anda 1. ve 2. sınıfa devam eden 54 okul öncesi öğretmen adayı olmak üzere toplam 97 okul öncesi öğretmen adayı ile 
Erzurum, İstanbul, İzmir, Ankara, Adana, Malatya ve Erzincan illerinde çocukları okul öncesi eğitim kurumlarına gönderen 245 veli araştırmanın örneklemini oluşturmuşlardır.

Araştırma kapsamına alınanların tanıtıcı özelliklerine göre dağılımları Tablo 1'de verilmiştir.

Tablo 1. Arasstrmaya Alnanlarn Tanttıı Özellikleri İle İlgili Bulgular (n=413)

\begin{tabular}{|c|c|c|c|c|c|c|c|}
\hline & & \multicolumn{2}{|c|}{ Ögrtetmen aday1 } & \multicolumn{2}{|c|}{ Öğretmen } & \multicolumn{2}{|c|}{$\overline{V e l i}$} \\
\hline & & $\mathrm{S}$ & $\%$ & $S$ & $\%$ & $\mathrm{~S}$ & $\%$ \\
\hline \multirow{6}{*}{ Yaş } & 20 yaş ve altı & 60 & 61,9 & 0 & 0 & 2 & 0 \\
\hline & $21-25$ yaş & 32 & 33,0 & 3 & 4,2 & 7 & 2,8 \\
\hline & $26-30$ yaş & 3 & 3,1 & 5 & 7 & 53 & 21,6 \\
\hline & $31-35$ yaş & 2 & 2,1 & 20 & 28,2 & 98 & 40,0 \\
\hline & $36-40$ yaş & 0 & 0,0 & 18 & 25,4 & 70 & 28,6 \\
\hline & 41 yaş ve üstü & 0 & 0,0 & 25 & 35,2 & 17 & 6,9 \\
\hline \multirow{2}{*}{ Cinsiyet } & Kadın & 78 & 80,4 & 63 & 88,7 & 227 & 92,7 \\
\hline & Erkek & 19 & 19,6 & 8 & 11,3 & 18 & 7,3 \\
\hline \multirow{5}{*}{ Eğitim durumu } & İlkokul & 0 & 0,0 & 0 & 0,0 & 21 & 8,6 \\
\hline & Ortaokul & 0 & 0,0 & 0 & 0 & 27 & 11,0 \\
\hline & Lise/ Önlisans & 0 & 0,0 & 1 & 1,4 & 79 & 32,2 \\
\hline & Üniversite & 97 & 100,0 & 60 & 84,5 & 93 & 38,0 \\
\hline & Lisansüstü & 0 & 0,0 & 10 & 14,1 & 25 & 10,2 \\
\hline
\end{tabular}

Tablo 1 incelendiğinde araştırmaya katılan okul öncesi öğretmen adaylarının; \% 61,9’u 20 yaş ve altı, \% 33’ü 21-25 yaşında, \% 3,1'i 26-30 yaşında, \% 2'si 31-35 yaşında olduğu belirlenmiştir. Okul öncesi öğretmenlerinin, \% 4,2'si 21-25 yaşında, \% 7'si 26-30 yaşında, \% 28,2'si 31-35 yaşında, \% 25,4'ü 36-40 yaşında, \% 35,2'si 41 yaş ve üstünde olduğu belirlenmiştir. Araştırmaya katılan velilerin \% 2'si 21-25 yaşında, \% 22'si 26-30 yaşında, \% 40’1 31-35 yaşında, \% 28,6's1 36-40 yaşında, \% 7,4'ü 41 yaş ve üstünde olduğu tespit edilmiştir. Okul öncesi öğretmen adaylarının \% 80,4’ü kadın, \% 19,6'sının erkek olduğu, okul öncesi öğretmenlerin \% 88,7'si kadın, \% 11,3’ü erkek olduğu, velilerin \% 92,7'si kadın, \% 7,3'ü erkek olduğu tespit edilmiştir. Okul öncesi öğretmen adaylanının, \% 100’ü üniversite eğitimi aldığı, okul öncesi öğretmenlerinin \% 1,4'ü ön lisans mezunu, \% 84,5’i üniversite mezunu, \% 14,1'i lisansüstü mezunu oldukları belirlenmiştir. Araştırmaya katılan velilerinin \% 8,6's1 ilkokul mezunu, \% 11'i ortaokul mezunu, \% 32,2’si lise mezunu, \% 38’i üniversite mezunu, \% 10,2'si lisansüstü mezunu olduğu görülmektedir.

\section{Veri Toplama Araçları}

Araştırmada veri toplama aracı olarak araştırmacının kendisi tarafından geliştirilen "Demografik Bilgi Toplama Formu” ile Karaman-Kepenekçi (2006, s. 307-319) tarafindan geliştirilen "Çocuk Haklarına İlişkin Tutum Ölçeği” kullanılmıştır. Demografik bilgi formu araştırmacının kendisi tarafından oluşturulmuş olup, örneklem grubunda yer alan okul öncesi öğretmenlerine, okul öncesi öğretmen adaylarına ve okul öncesi eğitimde çocuğu şu anda eğitim gören ebeveynlerin yaş, cinsiyet ve eğitim durumları değişkenlerinin belirlenmeyi amaçlamaktadır.

Araştırmada veri toplama aracı olarak kullanılan diğer bir ölçekte Karaman-Kepenekçi (2006) tarafından geliştirilen "Çocuk Haklarına İlişkin Tutum Ölçeği” dir. Çocuk haklarına ilişkin tutum ölçeği (ÇHTÖ) bu araştırmada okul öncesi öğretmenlerine, okul öncesi öğretmen adaylarına ve şu anda okul Öncesi eğitimde çocukları bulunan ebeveynlere uygulanmıştır. Ölçek 5'li likert tipinde hazırlanmış olup "tamamen katiliyorum", "katiliyorum", "kararsızım”, "katiliyorum” ve "tamamen katilmiyorum" ifadeleri bulunmaktadır. Çocuk Haklarına İlişkin Tutum Ölçeği, çocukların yaşamsal, gelişimsel, korunma ve katılım haklarını içerek toplam 22 maddeden oluşmaktadır. Ölçekte 19'u olumlu, 3'ü olumsuz ifade bulunmaktadır. Bu nedenle olumsuz ifadeler ters puanlanmaktadır. İfadelere verilen tepkiler aynı sırayla 1, 2, 3, 4 ve 5 olarak puanlanmakta olup, ölçekten alınan puanın yüksek olması olumsuz tutumu göstermektedir. Ölçekteki olumsuz ifadelere (2.14. ve 15. maddeler) verilen tepkiler ters puanlanmaktadır (Karaman-Kepenekçi, 2006, s. 307-319).

Ölçekten alınacak olan en düşük puan 22, en yüksek puan ise 110'dur. Karaman-Kepenekçi (2006, s. 307-319) tarafından ölçeğin geçerlik ve güvenirlik çalışması yapılmış olup, ölçeğin tek faktörlü olduğu belirlenmiştir. Ölçekteki maddelerin madde korelasyon katsayılarının. 32 ile. 61 arasında değiştiği saptanmıştır. Güvenirlik çalışması doğrultusunda da Cronbach Alpha iç tutarlılık katsayısını. 85, yarı test güvenirlik katsayısının ise .77 olarak belirlenmiştir. Yapılan bu araştırmada ise güvenirlik cronbach alpha değerinin. 896 yüksek olarak bulunmuştur. 
Araştırmayla ilgili Bayburt Üniversitesi Etik Kurul'undan 12.03.2020 tarihli ve 79126184-050.99/E. 6399 sayılı yazıya istinaden etik kurul izin onayı alınmıştır. Araştırmada veri toplama aracı olarak "Demografik Bilgi Formu" ve "Çocuk Haklarına İlişkin Tutum Ölçeği” kullanılmıştır. Araştırmada kullanılan form ve ölçek, elektronik ortama aktarılarak örneklemde yer alan okul öncesi ögretmenlerine, üniversitelerin okul öncesi öğretmenliği bölümünde lisans eğitimi alan ve araştırmaya gönüllü olarak katılmak isteyen okul öncesi öğretmen adaylarına ve okul öncesi eğitime şu anda devam etmekte olan çocukları bulunan velilere sunulmuş ve kendilerinden (google driver) https:// forms.gle/sKJd44q8d48ovAHdA linki üzerinden bu formları doldurmaları istenmiştir.

\section{Verilerin Analizi}

Araştırmada elde edilen verilerin istatistiksel analizi için SPSS programı kullanılmıştır. Elde edilen verilerin, ne tür testlerle analiz edileceğini belirlemek için Çocuk haklarına ilişkin tutum ölçeğinden elde edilen verilerin normal dağılım gösterip göstermediğine yönelik analizler yapılmıştır. Yapılan analizler sonucu Skewness ve Kurtosis değerlerinin tümü -1.96 ile +1.96 aralığının dışında bulunmuştur. Ayrıca Kolmogrov-Smirnov testi analizi sonucu $\mathrm{p}<0.05$ önem düzeyinde anlamlı bulunduğundan verilerin normal dağılıma uygun olmadığı görülmüştür.

Tablo 2. Normal Dağllım Analizleri

\begin{tabular}{lccc}
\hline & Skewness & Kurtosis & Kolmogov-Smimov \\
\hline Çocuk Haklarına İlişkin Tutum Ölçeği & 4,166 & 25,386 &, 194 \\
\hline
\end{tabular}

$\mathrm{Bu}$ nedenle araştırmada verilerin analizinde frekans, yüzde ve non-parametrik testlerden Kruskal Wallis H-testi, Dunnett T3 Post Hoc testi ve Mann Whitney U-testi kullanılmıştır.

\section{Bulgular}

Tablo 3. ÇHÖ Puanlarna İliskin Aritmetik Ortalama ve Standart Sapma Değerleri

\begin{tabular}{|c|c|c|c|c|c|c|c|}
\hline & & $N$ & $\begin{array}{c}\text { Aritmetik } \\
\text { ortalama }\end{array}$ & S.s. & $\begin{array}{c}\text { Sira } \\
\text { ortalamas1 }\end{array}$ & $K W$ & $p$ \\
\hline \multirow{4}{*}{$\begin{array}{l}\text { Çocuk Haklarına İlişkin } \\
\text { Tutum Ölçeği }\end{array}$} & Öğretmen aday1 & 97 & 31,79 & 10,638 & 174,58 & 16,458 &, 000 \\
\hline & Öğretmen & 71 & 32,07 & 10,997 & 183,82 & & \\
\hline & Veli & 245 & 35,19 & 11,503 & 226,55 & & \\
\hline & Toplam & 413 & 33,85 & 11,308 & & & \\
\hline
\end{tabular}

Tablo 3 incelendiğinde okul öncesi öğretmen adaylarının ÇHTÖ aldıkları puanların ortalamasının $31.79 \pm 10.638$, okul öncesi öğretmenlerin $32.07 \pm 10.997$, velilerin $35.19 \pm 11.503$ olduğu ve aralarındaki farka ait Kruskal Wallis $\mathrm{H}$ testi sonucu $\mathrm{p}<0.05$ önem düzeyinde anlamlı bulunmuştur $(\mathrm{KW}=16.458$ $\mathrm{p}=.000)$. Bu bulgu okul öncesi öğretmen adaylarının, okul öncesi öğretmenlerin ve velilerin ÇHTÖ aldıkları puanlar arasında fark olduğunu göstermektedir. Farkın hangi gruptan kaynaklandığını anlamak için Dunnett T3 Post Hoc testi uygulanmıș ve şu anda okul öncesi eğitim kurumlarına devam eden çocuğu olan velilerle; okul öncesi ögretmen adaylarının ÇHTÖ aldıkları puanların ortalamaları arasındaki farkın anlamlı olduğu saptanmıştır. Velilerin ÇHTÖ puan ortalamasının; okul öncesi öğretmen adaylarından daha yüksek olduğu bulunmuştur. Bu nedenle okul öncesi öğretmen adaylarının velilere göre çocuk haklarına ilişkin tutumlarının daha olumlu olduğu söylenebilir.

Okul öncesi öğretmen adaylarının, okul öncesi öğretmenlerin ve velilerin yaşlarına göre ÇHTÖ puanları açısından farklar incelenmiştir. 
Tablo 4. Okul Öncesi Öğretmen Adaylarınn, Okul Öncesi Ögretmenlerin Ve Velilerin Yaslarına Göre CHTÖ Aldiklar Puanlar Arasindaki Farklar

\begin{tabular}{|c|c|c|c|c|c|c|c|}
\hline & & $N$ & $\begin{array}{c}\text { Aritmetik } \\
\text { ortalama }\end{array}$ & S.s. & $\begin{array}{c}\text { Sira } \\
\text { ortalamas1 }\end{array}$ & $K W$ & $p$ \\
\hline \multirow{4}{*}{ Öğretmen adayı } & 20 yaş ve altı & 60 & 31,03 & 9,558 & 47,67 & 4,067 & ,254 \\
\hline & $21-25$ yaş & 32 & 33,88 & 12,715 & 54,52 & & \\
\hline & $26-30$ yaş & 3 & 29,00 & 9,644 & 35,67 & & \\
\hline & $31-35$ yaş & 2 & 25,50 &, 707 & 20,75 & & \\
\hline \multirow{5}{*}{ Öğretmen } & $21-25$ yaş & 4 & 35,33 & 12,342 & 42,17 & 6,572 & ,254 \\
\hline & $26-30$ yaş & 4 & 33,50 & 1,915 & 52,13 & & \\
\hline & $31-35$ yaş & 20 & 34,95 & 18,889 & 35,00 & & \\
\hline & $36-40$ yaş & 18 & 29,44 & 6,662 & 27,89 & & \\
\hline & 41 yaş ve üstü & 25 & 31,00 & 3,266 & 38,70 & & \\
\hline \multirow{5}{*}{ Veli } & $21-25$ yaş & 7 & 43,20 & 23,414 & 146,10 & 4,457 & ,486 \\
\hline & $26-30$ yaş & 53 & 34,19 & 9,652 & 121,23 & & \\
\hline & $31-35$ yaş & 98 & 36,33 & 13,263 & 128,38 & & \\
\hline & $36-40$ yaş & 70 & 33,19 & 8,268 & 113,61 & & \\
\hline & 41 yaş ve üstü & 17 & 38,59 & 12,052 & 136,53 & & \\
\hline \multirow{6}{*}{ Tümü } & 20 yaş altı & 60 & 30,94 & 9,382 & 166,10 & 12,064 & ,034 \\
\hline & $21-25$ yaş & 43 & 35,15 & 14,219 & 210,26 & & \\
\hline & $26-30$ yaş & 60 & 33,88 & 9,314 & 213,85 & & \\
\hline & $31-35$ yaş & 120 & 35,92 & 14,230 & 225,97 & & \\
\hline & $36-40$ yaş & 88 & 32,42 & 8,074 & 196,78 & & \\
\hline & 41 yaş ve üstü & 42 & 34,07 & 8,783 & 222,69 & & \\
\hline
\end{tabular}

Tablo 4 incelendiğinde okul öncesi öğretmen adaylarının yaşlarına göre ÇHTÖ aldıkları puanlar açısından aralarındaki farka ait Kruskal Wallis $\mathrm{H}$ testi sonucu $\mathrm{p}>0.05$ önem düzeyinde anlamsız bulunmuştur $(\mathrm{KW}=4.067 \mathrm{p}=.254)$. Bu bulgu okul öncesi öğretmen adaylarının yaşlarına göre ÇHTÖ aldıkları puanlar arasında fark olmadığını yani benzer olduğunu göstermektedir. Okul öncesi öğretmenlerin yaşlarına göre ÇHTÖ aldıkları puanlar açısından aralarındaki farka ait Kruskal Wallis $\mathrm{H}$ testi sonucu $\mathrm{p}>0.05$ önem düzeyinde anlamsız bulunmuştur $(\mathrm{KW}=6.572 \mathrm{p}=.254)$. Bu bulgu öğretmenlerin yaşlarına göre ÇHTÖ aldıkları puanlar arasında fark olmadığını yani benzer olduğunu göstermektedir.

Velilerin yaşlarına göre ÇHTÖ aldıkları puanlar açısından aralarındaki farka ait Kruskal Wallis H testi sonucu $\mathrm{p}>0.05$ önem düzeyinde anlamsız bulunmuştur $(\mathrm{KW}=4.457 \mathrm{p}=.486)$. Bu bulgu velilerin yaşlarına göre ÇHTÖ aldıkları puanlar arasında fark olmadığını yani benzer olduğunu göstermektedir. Araştırmaya katılanların tümünün yaşlarına göre ÇHTÖ aldıkları puanlar açısından aralarındaki farka ait Kruskal Wallis $\mathrm{H}$ testi sonucu $\mathrm{p}<0.05$ önem düzeyinde anlamlı bulunmuştur $(\mathrm{KW}=12.064 \mathrm{p}=.034)$. Bu bulgu araştırmaya katılanların tümünün yaşlarına göre ÇHTÖ aldıkları puanlar arasında fark olduğunu göstermektedir. Dunnett T3 Post Hoc testi sonucu farkın 31-35 yaş ile 20 yaş altı grubundaki kişilerden kaynaklandığı saptanmıştır. 31-35 yaşındakilerin ÇHTÖ aldıkları puan ortalamasının 20 yaş altındakilerinden daha yüksek olduğu bulunmuştur. Bu nedenle 20 yaş altı aralığındakilerin 31-35 yaş aralığındakilere göre çocuk haklarına ilişkin tutumlarının daha olumlu olduğu söylenebilir.

Okul öncesi öğretmen adaylarının, okul öncesi öğretmenlerin ve velilerin cinsiyetlerine göre ÇHTÖ aldıkları puanlar açısından farklar incelenmiştir.

Tablo 5. Okul Öncesi Ögretmen Adaylarmm, Okul Öncesi Öğretmenlerin ve Velilerin Cinsiyetlerine Göre Chtö Aldiklar Puanlar Arasindaki Farklar

\begin{tabular}{|c|c|c|c|c|c|c|}
\hline & Cinsiyet & $N$ & Sira or & Sira toplami & $U$ & $p$ \\
\hline \multirow{2}{*}{ Öğretmen adayı } & Kadın & 227 & 46,36 & 3616,00 & \multirow[t]{2}{*}{535,000} & \multirow[t]{2}{*}{, 061} \\
\hline & Erkek & 18 & 59,84 & 1137,00 & & \\
\hline \multirow{2}{*}{ Öğretmen } & Kadın & 63 & 37,01 & 2331,50 & \multirow[t]{2}{*}{188,500} & \multirow[t]{2}{*}{247} \\
\hline & Erkek & 8 & 28,06 & 224,50 & & \\
\hline \multirow{2}{*}{ Veli } & Kadın & 227 & 122,63 & 27836,00 & \multirow[t]{2}{*}{1958,000} & \multirow[t]{2}{*}{,769 } \\
\hline & Erkek & 18 & 127,72 & 2299,00 & & \\
\hline \multirow{2}{*}{ Tümü } & Kadın & 368 & 206,17 & 75869,50 & \multirow[t]{2}{*}{7973,500} & \multirow[t]{2}{*}{,685 } \\
\hline & Erkek & 45 & 213,81 & 9621,50 & & \\
\hline
\end{tabular}


Tablo 5 incelendiğinde okul öncesi öğretmen adaylarının cinsiyetlerine göre ÇHTÖ aldıkları puanların aralanndaki farklara ait Mann Whitney $U$ testi sonucu $\mathrm{p}>0.05$ önem düzeyinde anlamsız bulunmuştur $(\mathrm{U}=535.000 \mathrm{p}=.061)$. Bu bulgu velilerin cinsiyetlerine göre ÇHTÖ aldıkları puanlar arasında fark olmadığını yani benzer olduğunu göstermektedir.

Okul öncesi öğretmenlerinin cinsiyetlerine göre ÇHTÖ aldıkları puanların aralarındaki farka ait Mann Whitney $\mathrm{U}$ testi sonucu $\mathrm{p}>0.05$ önem düzeyinde anlamsız bulunmuştur ( $\mathrm{U}=188.500 \mathrm{p}=.247)$. Bu bulgu öğretmenlerin cinsiyetlerine göre ÇHTÖ aldıkları puanlar arasında fark olmadığını yani benzer olduğunu göstermektedir. Velilerin cinsiyetlerine göre ÇHTÖ aldıkları puanların aralarındaki farka ait Mann Whitney $\mathrm{U}$ testi sonucu $\mathrm{p}>0.05$ önem düzeyinde anlamsız bulunmuştur ( $\mathrm{U}=1958.000 \mathrm{p}=.769)$. Bu bulgu velilerin cinsiyetlerine göre ÇHTÖ aldıkları puanlar arasında fark olmadığını yani benzer olduğunu göstermektedir. Araştırmaya katılanların tümünün cinsiyetlerine göre ÇHTÖ aldıkları puanların aralarındaki farka ait Mann Whitney $U$ testi sonucu $\mathrm{p}>0.05$ önem düzeyinde anlamsız bulunmuştur $(\mathrm{U}=7973.500 \mathrm{p}=.685)$. Bu bulgu araştırmaya katılanların tümünün cinsiyetlerine göre ÇHTÖ aldıkları puanlar arasında fark olmadığını yani benzer olduğunu göstermektedir.

Okul öncesi öğretmen adayların, okul öncesi öğretmenlerin ve velilerin eğitim durumlarına göre ÇHTÖ aldıkları puanlar farklar incelenmiştir.

Tablo 6. Okul Öncesi Ögretmen Adaylarnnn, Okul Öncesi Ögrretmenlerin ve Velilerin Eğitim Durumlarna Göre Chtö Aldiklar Puanlar Arasindaki Farklar

\begin{tabular}{|c|c|c|c|c|c|}
\hline & & $\mathrm{N}$ & Sira ortalamas1 & $\mathrm{KW}$ & $\mathrm{p}$ \\
\hline Öğretmen adayı & & & & $*$ & \\
\hline \multirow{4}{*}{ Öğretmen } & Ortaokul & 1 & 56,50 & 3,502 & ,322 \\
\hline & Lise & 1 & 3,50 & & \\
\hline & Üniversite & 60 & 36,26 & & \\
\hline & Lisansüstü & 9 & 35,61 & & \\
\hline \multirow{5}{*}{ Veli } & İlkokul & 21 & 114,02 & 6,512 & ,164 \\
\hline & Ortaokul & 27 & 140,70 & & \\
\hline & Lise & 79 & 123,04 & & \\
\hline & Üniversite & 93 & 113,48 & & \\
\hline & Lisansüstü & 25 & 146,70 & & \\
\hline \multirow{5}{*}{ Tümü } & İlkokul & 21 & 215,02 & 13,467 & ,009 \\
\hline & Ortaokul & 28 & 253,82 & & \\
\hline & Lise & 85 & 221,15 & & \\
\hline & Üniversite & 245 & 190,86 & & \\
\hline & Lisansüstü & 34 & 194,44 & & \\
\hline
\end{tabular}

* Hepsi üniversite eğitiminde olduğu için analiz yapılmamıştır.

Tablo 6 incelendiğinde okul öncesi öğretmenlerin eğitim durumlarına göre ÇHTÖ aldıkları puanların aralarındaki farka ait Kruskal Wallis $\mathrm{H}$ testi sonucu $\mathrm{p}>0.05$ önem düzeyinde anlamsız bulunmuştur $(\mathrm{KW}=3.502 \mathrm{p}=.322)$. Bu bulgu okul öncesi öğretmenlerinin eğitim durumlarına göre ÇHTÖ aldıkları puanlar arasında fark olmadığını yani benzer olduğunu göstermektedir.

Velilerin eğitim durumlarına göre ÇHTÖ aldıkları puanların aralarındaki farka ait Kruskal Wallis $\mathrm{H}$ testi sonucu $\mathrm{p}>0.05$ önem düzeyinde anlamsız bulunmuştur $(\mathrm{KW}=6.512 \mathrm{p}=.164)$. Bu bulgu velilerin eğitim durumlarına göre ÇHTÖ aldıkları puanlar arasında fark olmadığını yani benzer olduğunu göstermektedir.

Araştırmaya katılanların tümünün eğitim durumlarına göre ÇHTÖ aldıkları puanların aralarındaki farka ait Kruskal Wallis $\mathrm{H}$ testi sonucu $\mathrm{p}<0.05$ önem düzeyinde anlamlı bulunmuştur $(\mathrm{KW}=13.467$ $\mathrm{p}=.009)$. Bu bulgu araştırmaya katılanların tümünün eğitim durumlarına göre ÇHTÖ aldıkları puanlar arasında fark olduğunu göstermektedir. Dunnett T3 Post Hoc testi sonucu farkın eğitimi ortaokul olanlarla eğitimi üniversite olan, eğitimi lisansüstü olanlarla eğitimi ilkokul, ortaokul, lise olan kişilerden kaynaklandığ1 saptanmıştır. Eğitimi ortaokul olanların ÇHTÖ aldıkları puan ortalamasının eğitimi üniversite olanlardan daha yüksek olduğu, eğitimi ilkokul, ortaokul, lise olanların ÇHTÖ aldıkları puan ortalamasının eğitimi lisansüstü olanlardan daha yüksek olduğu bulunmuştur. Bu nedenle, eğitim düzeyi üniversite olanların, eğitim düzeyi ortaokul olanlara göre, eğitim düzeyi lisansüstü olanların eğitimi ilkokul, ortaokul ve lise düzeyinde olanlara göre çocuk haklarına ilişkin tutumlarının daha olumlu olduğu söylenebilir. 


\section{Tartışma, Sonuç ve Öneriler}

Bu çalışmada okul öncesi öğretmen adaylarının, okul öncesi öğretmenlerinin ve şu anda okul öncesi eğitime devam eden çocukları olan velilerin "Çocuk haklarına ilişkin tutumları" belirlenmeye çalışılmıştır. Bu kapsamda örneklem grubunda yer alan kişilerin demografik bilgilerinden elde edilen sonuçlara göre okul öncesi öğretmen adaylarının çoğunun \% 61,9'unun 20 yaş altı aralığında olduğu; \% 80,4 kadın öğretmen adaylarından oluştuğu ve öğretmen adaylarının tamamının lisans düzeyinde eğitim aldıkları tespit edilmiştir. Ayrıca okul öncesi öğretmen adaylarının çoğunun \% 35,2'si 41- yaş ve üstü aralığında olduğu \% 88,7'sinin kadın olduğu; öğretmenlerin büyük çoğunluğunun \% 84,5'inin lisans mezunu oldukları belirlenmiştir. Bununla birlikte velilerin çoğunun \% 40'ının 31-35 yaş aralığında olduğu \% 92,7’sinin kadın olduğu ve \% 38 'inin lisans mezunu oldukları tespit edilmiştir. Araştırmadan elde edilen bu sonuçlara göre okul öncesi aday öğretmenlerinin, okul öncesi öğretmenlerinin ve velilerin büyük çoğunluğunun kadın okul öncesi öğretmen adayı, kadın öğretmenler ve kadın velilerden oluşması dikkat çekicidir. Bu sonuçlardan yola çıkarak Türkiye'de okul öncesi eğitime, okul öncesi öğretmen adayları, okul öncesi öğretmenleri ve veli boyutunda bakıldığında bu eğitim kademesinin kadınlarla özdeşleştirildiği ve kültürel değerlerin bu anlamda hala meslek seçiminde önemli bir etken olduğunu söylemek mümkündür. İlgili literatür tarandığında bu araştırma sonuçlarını destekleyen başka araştırma sonuçlarına da rastlanmışır. Birey ve Beyidoğlu Onen (2013, s. 26-27) yaptıkları çalışmalarında her iki bayan öğretmenden birinin ve her üç erkek öğretmenden ikisinin okul öncesi öğretmenlerinin kadın olması gerektiğini ifade ettikleri sonucuna ulaşmışlardır. Bununla birlikte Akman, Taşkın, Ozden, Okyay ve Cortu (2014, s. 21-32) yaptıkları çalışmalarında velilerin okul öncesi eğitimde öğretmen cinsiyetine özel bir önem vermediği ancak bazı ailelerin okul öncesi eğitimi bayan işi olarak değerlendirdiklerini, bu algının kalıplaşmış ve geleneksel cinsiyet rollerinden kaynaklandığı tespit etmişlerdir. Bu araştırma sonucundan da anlaşıldığı gibi eğitimin yapısında var olan hızlı değişim ve gelişim süreçlerinin yansımalan kültürel değerler üzerinde biraz daha yavaş gerçekleşmekte ve zaman almaktadır.

Okul öncesi öğretmen adaylarının ve öğretmenlerinin üniversite mezunu olmaları öğretmenliğe atanma kriterlerini yerine getirebilmeleri açısından şart olduğundan anlaşılabilir bir durum olarak karşımıza çıkmaktadır. Bununla birlikte araştırmanın örneklem grubuna giren velilerin büyük çoğunluğunun kadın ebeveynlerden oluşması ilginç bir durum olarak karşımıza çıkmaktadır. Asıl dikkat çekici olan durum ise okul öncesi eğitimde çocukları bulunan velilerin önemli bir bölümünün lisans düzeyinde eğitim almış olmalarıdır. Bu durum velilerin eğitimdeki rolü ve katkıları düşünüldügünde bilinçli nesiller yetiştirmek adına gelecek açısından umut vericidir. Bu araştırma sonucuna benzer bir araştırma sonucuna da; Fantuzzo, Tighe ve Chields'in (2000, s. 367-376) yaptıkları çalışmalarında velilerin eğitim düzeyi ile okullardaki etkinliklere yüksek seviyede veli katılımı arasında pozitif yönlü bir ilişki olduğu sonucuna ulaşmışlardır. Öte yandan literatür taramasında bu araştırma sonuçlarıyla tamamen ters olan araştırma sonuçlarına da ulaşılmıştır. Velilerin eğitim düzeyinin okullardaki veli katılımlarını etkilemediğini tespit eden araştırma sonuçlarına da ulaşılmıştır (Erdener, 2013, s. 102). Ayrıca Ertem ve Gökalp'in (2020, s. 7891) yaptıkları çalışmalarında ise ilköğretim mezunu velilerin okulu daha pozitif algılamakta ve okuldaki etkinliklere daha fazla katıldıkları sonucuna ulaşmışardır.

Araştırmadan elde edilen diğer bir sonuca göre okul öncesi öğretmen adaylarının, okul öncesi öğretmenlerinin ve velilerin çocuk haklarına ilişkin tutum ölçeğinden aldıkları (ÇHTÖ) puanların ortalamaları arasında anlamlı fark olduğu belirlenmiştir. Bu anlamlı farkın okul öncesi öğretmen adayları ile veliler arasında ki gruplardan kaynaklandığı görülmüştür. Ortaya çıkan bu sonuç doğrultusunda okul öncesi öğretmen adaylarının çocuk haklarına ilişkin tutumlarının okul öncesi eğitimde şu anda çocuğu bulunan velilere göre daha olumlu olduğunu söylemek mümkündür. İlgili literatür taramasında bu araştırma sonuçlarıyla benzerlik gösteren başka araştırma sonuçlarına da rastlanmıştır. Doğan, Torun ve Akgün (2014, s. 503-516) araştırmasında okul öncesi öğretmen adaylarının çocuk haklarına ilişkin tutum puanlarının yüksek olduğu sonucuna ulaşmışır. Leblebici ve Çeliköz (2016, s. 307-318), yaptıkları çalışmasında örneklem grubu içerisinde okul öncesi öğretmen adaylarının da olduğu çalışmasında öğretmen adaylarının çocuk haklarına yönelik genel tutumlarının oldukça yüksek düzeyde olumlu olduğunu tespit etmiştir. Dinç (2015, s. 7-25) çalısmasında okulöncesi eğitim kurumuna devam eden çocukların ebeveynlerinin çocuk hakları eğitim konusundaki görüşlerini araştırdığı çalışmasında ebeveynlerin çocuk hakları konusunu yeterince bilmedikleri ve bilinçlendirmeye ihtiyaç duydukları sonucuna ulaşmıştır. Quennerstedt'in (2011, s. 661-678) konuyla ilgili meta analiz çalışmasında, çocuk hakları ve kattlım hakkının sağlanabilmesi için velilerin çocuk hakları konusunda bilinçlendirilmesi gerektiğini vurgulamıştır. Ayrıca ilgili literatür tarandığında bu araştırma sonuçlarıyla benzerlik göstermeyen araştırma sonuçlarına da 
rastlanmıştır. Akgül'ün (2015, s. 64) çalışmasında, ebeveynlerin çocuk haklarının önemli olduğunu ifade ettikleri ve sırasıyla yaşama, eğitim, gelişim ve korunma hakkına vurgu yaptıklarını belirlemiştir. Yapılan bu araştırmada ortaya çıkan bu araştırma sonuçlarının nedeni okul öncesi öğretmen adaylarının tamamının lisans düzeyinde eğitim almaları ve bu anlamda araştırmaya katılan velilerin çoğunluğunun \% 51,8' inin ilkokul, ortaokul, lise ve ön lisans mezunu olmalarından kaynaklanıyor olabilir.

Diğer bir araştırma sonucuna göre okul öncesi öğretmen adaylarının, okul öncesi öğretmenlerinin ve velilerin yaşlarına göre ÇHTÖ aldıkları puanlar açısından aralanındaki farka ait değerler yapılan analizler sonucunda önem düzeyinde anlamsız bulunmuştur. Bu sonuçlara dayanarak okul öncesi öğretmen adaylarının, okul öncesi öğretmenlerinin ve velilerin çocuk haklarına ilişkin tutumları üzerinde yaşın belirleyici bir etken olmadığı söylenilebilir. Örneklem grupları farklı olmakla birlikte bu araştırma sonuçlarını destekleyen bir araştırma; Tüysüzer (2018, s. 96) yaptığı çalışmasında okul yöneticilerinin çocuk haklarına ilişkin tutumlarının yaş değişkenine göre değişmediğini, diğer bir araştırma ise Yaşar-Ekici (2014) yılında yaptıkları çalışmalarında öğretmen adaylarının çocuk haklarına yönelik tutumlarının yaş değişkenine göre farklılaşmadığı sonucuna ulaştıkları çalışmalarıdır.

Bununla birlikte araştırmaya katılanların tümünün yaşlarına göre ÇHTÖ aldıkları puanların aralarındaki farka bakıldığında aldıkları puanlar arasında fark olduğu belirlenmiştir. Yapılan analizler sonucunda farkın 31-35 yaş ile 20 yaş altı grubundaki kişilerden kaynaklandığ1 tespit edilmiştir. 20 yaş altı grubundaki kişilerin çocuk haklarına ilişkin tutumlarının 31-35 yaş grubundaki kişilere göre daha olumlu olduğunu sonucuna ulaşılmıştır. İlgili literatür incelemesinde bu araştırma sonucunu destekleyen veya desteklemeyen herhangi bir araştırma sonucuna rastlanılmamıştır. Bu sonuçlar doğrultusunda 20 yaş altı aralığında yer alan kişilerin tamamını okul öncesi öğretmen adaylarının oluşturduğu; 31-35 yaş aralı̆̆ında örneklem grubunda yer alan kişilerin çoğunluğunu ise sırasıyla veliler, okul öncesi öğretmenleri ve okul öncesi öğretmen adaylarının oluşturduğu görülmektedir. Bu sonuçlar doğrultusunda araştırmaya katılan öğretmen adaylarının \% 61,9' unun 20 yaş altı aralığında olmaları onların kısmen de olsa çocuk sayılabilecek yaş aralığında bulunmaları ve bu nedenle konuyla ilgili empati yapma düzeylerinin diğer yaş aralığında yer alan kişilere göre daha yüksek olmalarından kaynaklanıyor olabilir.

Öte yandan okul öncesi öğretmen adaylarının, öğretmenlerinin ve velilerinin cinsiyetlerine göre ÇHTÖ aldıkları puanlar arasında farkın önem düzeyinde anlamsız olduğu tespit edilmiştir. Bu sonuca göre örneklem grubunda yer alan kişilerin cinsiyetlerinin çocuk haklarına ilişkin tutumları üzerinde belirleyici bir etken olmadığını söylemek mümkündür. Literatür incelendiğinde araştırmanın örneklem gruplarıyla farklı sonuçlarıyla benzer araştırma sonuçlarına ulaşılmışır (Tüysüzer, 2018, s. 1-129; Dönmez; 2015, s. 73-74; Karaman-Kepenekci ve Baydık, 2009, s. 329-350).

Okul öncesi öğretmenlerin ve velilerinin eğitim durumlarına göre ÇHTÖ aldıkları puanların aralarındaki farkın önem düzeyinde anlamsız olduğu bulunmuştur. Bu nedenle okul öncesi öğretmenlerinin ve velilerinin eğitim durumlarının çocuk haklanna ilişkin tutumlanı üzerinde belirleyici bir etken olmadığı tespit edilmiştir. Bununla birlikte araştırmaya katılan okul öncesi öğretmen adaylarının tamamının lisans düzeyinde hali hazırda eğitim alıyor olmalarından dolayı bu kapsamda bir analize gerek duyulmamıstır. Öte yandan araştırmaya katılanların tümünün eğitim durumlarına göre ÇHTÖ aldıkları puanların aralarındaki farka ait yapılan testler sonucunda bu farklar önem düzeyinde anlamlı bulunmuştur. Bu farkın eğitim düzeyi üniversite olanların ortaokul mezunlarına göre; eğitim düzeyi lisansüstü olanların, eğitim düzeyleri ilkokul, ortaokul ve lise düzeyinde olanlara göre çocuk haklarına ilişkin tutumlarının daha olumlu olduğu belirlenmiştir. Konuyla ilgili literatür tarandığında örneklem gruplarında yer alan okul öncesi öğretmen adaylarının, okul öncesi öğretmenlerinin ve okul öncesi eğitimde şu anda çocukları bulunan velilerin eğitim durumlarına göre çocuk haklarına ilişkin tutumlarının değişip değişmediğini belirlemeye ve karşılaştırmaya yönelik herhangi bir çalışmaya rastlanılmamıştır. Sonuç olarak örneklem grubunda yer alan okul öncesi öğretmen adaylarının, öğretmenlerinin ve velilerin eğitim durumlanna ilişkin çocuk haklarına ilişskin tutumlarının ayrı ayrı değerlendirildiğinde çocuk haklarına ilişkin tutumlarının değişmediği ancak örneklem grubunda yer alan kişilerin tümünün eğitim durumlarına göre çocuk haklarına ilişkin tutumları karşılaştırıldığında eğitim durumları lisansüstü ve üniversite düzeyinde olan okul öncesi öğretmen adaylan, öğretmenleri ve velilerinin çocuk haklarına ilişkin tutumlarının; eğitim düzeyi ön lisans, lise, ortaokul ve ilkokul olan kişilere göre daha olumlu olduğu söylenilebilir. Görüldüğü gibi eğitim düzeyinin artmasıyla birlikte kişilerin çocuk haklarına ilişkin tutumlarının olumlu yönde değiştiğini ve bu nedenle toplumların eğitim seviyesindeki yükselişin çocuk haklarına ilişkin tutumlarını da olumlu yönde etkileyeceğini söylemek mümkündür. Bu sonuçlara dayanarak araştırmayla ilgili şu öneriler getirilebilir. 
- Okul öncesi eğitim kademesinin öğretmen adayı, öğretmen ve veli boyutuyla kadınlara yönelik bir meslek ve sorumluluk alanı algısını değiştirebilmek için adı geçen bu eğitim paydaşlarına hizmet öncesi dersler, hizmet içi kurslar ve veli katılımlarına dönük konuyla ilgili farkındalık yaratacak seminer ve konferanslar verilebilir.

- Araştırma sonuçlarında da görüldüğü gibi 20 yaş altı aralığındaki öğretmen adaylarının çocuk haklarına ilişkin tutumlarının 31-35 yaş aralığındaki okul öncesi öğretmenlerinden ve velilerinden daha olumlu olduğu görülmektedir. Bu sonuçtan hareketle bu yaş grubunda yer alan okul öncesi öğretmen adaylarının bu özelliklerini sahada kullanmalarına olanak sağlayacak çalısmalara üniversiteler ve Milli Eğitim Bakanlığı arasında yapılacak protokollerle alan açılabilir.

- Bu konu alanıyla ilgili çalışma örneklem grubu olarak okul öncesi öğretmen adayları, okul öncesi ögrretmenleri ve veliler üzerinde gerçekleştirilmiştir. Farklı örneklem grupları üzerinde ve farklı eğitim kademelerinde benzer çalışmalar yürütülebilir.

- Eğitim durumları değişkeninin okul öncesi eğitimdeki örneklem grupları açısından değerlendirildiğinde çocuk hakları tutumları üzerindeki etkisini belirlemeye yönelik çalışmaların çok sınırlı olduğu görülmektedir. Bu konu alanıyla ilgili yapılacak çalışmalara daha fazla yer verilebilir.

\section{Etik Beyan}

"Okul Öncesi Eğitim Paydaşlarmın Cocuk Haklarına İliskin Tutumlarını İncelenmesi” bașlıklı çalışmanın yazım sürecinde bilimsel kurallara, etik ve alıntı kurallarına uyulmuş; toplanan veriler üzerinde herhangi bir tahrifat yapılmamış ve bu çalışma herhangi başka bir akademik yayın ortamına değerlendirme için gönderilmemiştir.

\section{Kaynakça}

Akgül, M. Ş. (2015). Illkokul öğrenci velilerinin çocuk baklarna ilişkin görüslerinin değerlendirilmesi (Yüksek Lisans Tezi). Gaziosmanpaşa Üniversitesi Eğitim Bilimleri Enstitüsü, Tokat.

Akman, B., Taskin, N., Ozden, Z., Okyay, O. ve Cortu, F. (2014). Parents' views on the appointment of male teachers in Turkish pre-schools. Education as Change, 18(1), 21-32.

Alderson, P. (2000) Young children's rights: Exploring beliefs, principles and practice. London: Jessica Kingsley Publishers.

Archard, D. (1993) Children rights and childhood. London: Routledge.

Başaran, İ. E. (2005). Eğitim psikolojisi: gelişim, ögrenme ve ortam (6. Bask1). Ankara: Nobel Yayın Dağıtım.

Birey, T. ve Beyidoğlu Onen, M. (2013). Toplumsal cinsiyet ve ögretmenlik: Öğretmenlerin bakıs açısı (Gender and teaching profession: perspectives of teachers). Post Araştırma Enstitüsü (Post Research Institute).

Büyüköztürk, Ş. (2014). Deneysel desenler: Ön test- son test, kontrol grubu, desen ve veri analįi. Ankara: Pegem A.

Cilga. A. (2001). Çocuk hakları eğitimi. Milli Ĕ̈itim Dergisi, 151.

Covell, K., Howe, R. B. ve McNeil, J. K. (2010). Implementing children's human rights education in schools. Improving Schools, 13(2), 117-132.

Dağlı, S. K. (2015). Öğretmenlerin çocuk haklarna ilişkin davranışlarmmn ögrenciler tarafindan değerlendirilmesi (Yüksek Lisans Tezi). Yeditepe Üniversitesi Ĕgitim Bilimleri Enstitüsü, İstanbul.

Dinç, B. (2015). Okulöncesi eğitim kurumuna devam eden çocukların ebeveynlerinin çocuk hakları eğitimi konusundaki görüşleri. Eğitimde Nitel Arastırmalar Dergisi. Journal of Qualitative Research in Education, 3(1), 7-25.

Doğan, Y., Torun F. ve Akgün İ. H. (2014). Okul öncesi öğretmen adaylarının çocuk haklarına ilişkin tutumlarının çeşitli değişkenlere göre incelenmesi. International Journal of Human Sciences, 11(2), 503-516.

Dönmez T. (2015). İlkokul smi ögretmenlerinin sinf yönetimi profilleri ile çocuk haklarna yönelik tutumlar arasindaki ilişki (Yüksek Lisans Tezi). Gazi Üniversitesi Eğitim Bilimleri Enstitüsü, Ankara.

Erdener, M. A. (2013). Parents' perceptions of their involvement in schooling (Doktora Tezi). University of Clemson, South Carolina.

Ertem, H. Y. ve Gökalp, G. (2020). Velilerin okul iklimi ve veli katılımı algılarının velilerin eğitim durumu ve çocuklarının öğrenim kademesine göre incelenmesi. Hacettepe Üniversitesi Ë̆itim Fakültesi Dergisi, 35(1), 78-91.

Fantuzzo, J., Tighe, E. ve Childs, S. (2000). Family Involvement Questionnaire: A multivariate assessment of family participation in early childhood education. Journal of educational psychology, 92(2), 367-376.

Franklin, B. (2001). New handbook of children's rights: Comparative policy and practice. London: Routledge.

Gravetter, J. F. ve Forzano, L. B. (2012). Research methods for the behavioral sciences (4. Bask1). USA: Linda SchreiberGanster.

Hareket, E. (2019). Temel eğitim bölümü öğrencilerinin çocuk haklarına yönelik bilişsel algıları. Başkent Ünvversıty Journal of Education, 6(2), 167-180.

Hart, S. N. ve Pavlovic, Z. (1991). Children's rights in education: An historical perspective. School Psychology Review, 20(3), 345-358.

Hamon, H. (2006). Avrupa hukuku'nda çocuk ve genç adalet sistemi. Cocuk ve Genç Adalet Sistemi Sempozyumu, İstanbul: İstanbul Barosu Yayınları, s, 51-78. 
Kağıtçıbaşı, Ç. (2007). Kültürel psikoloji. İstanbul: Evrim Yayınevi.

Karaman-Kepenekci, Y. ve Baydık, B. (2009). Attitudes of the teacher candidates of mentally handicapped children about children's rights. Ankara University Journal of Faculty of Educational Sciences, 42(1), 329-350.

Karaman-Kepenekçi, Y. (2006). A study of university students' attitudes towards children's rights in Turkey. The International Journal of Children's Rights, 14(3), 307-319.

Karasar, N. (2012). Bilimsel araștırma yöntemi. Ankara: Nobel Yayıncılık.

Kor, K. (2013). Okul öncesi ögretmenlerinin çocuk haklar konusunda görüslerinin belirlenmesi (Yüksek Lisans Tezi). Çanakkale Onsekiz Mart Üniversitesi Eğitim Bilimleri Enstitüsü, Çanakkale.

Leblebici, H. ve Çeliköz N. (2016). Öğretmen adaylarının çocuk haklarına yönelik tutumları. International Journal of Social Sciences and Education Research, 3(1), 307-318.

Quennerstedt, A. (2011). The construction of children's rights in education- A research synthesis. The International Journal of Children's Rights, 19(18), 661-678.

Sağlam, M. ve Aral, N. (2016). Tarihsel süreç içerisinde çocuk ve çocukluk kavramları. Çocuk ve Medeniyet Dergisi, 1(2), 43-56.

Taşkın, Ö. Ö. (2006). Velayette çocuğun yü̈ksek yarar ilkesi (Yüksek Lisans Tezi). Anadolu Üniversitesi Sosyal Bilimler Enstitüsü. Eskișehir.

Tüysüzer, Ş. B. (2018). Okul yöneticilerinin çocuk haklarnna yönelik tutumlarmm belirlenmesi (Yüksek Lisans Tezi). İstanbul Sabahattin Zaim Üniversitesi, İstanbul.

Washington, F. (2010). 5-6 yass grubu cocuklarna uygulanan aile katulıml çocuk haklar eğitimi programmm etkililiğinin incelenmesi (Yüksek Lisans Tezi). Marmara Üniversitesi Eğitim Bilimleri Enstitüsü, İstanbul.

Yurtsever, M. (2009). Ebeveyn çocuk haklar tutum ölçĕ̈inin gelişstirilmesi ve anne babalarn çocuk baklarna yönelik tutumlarnmn farklı değişkenler açısından incelenmesi (Doktora Tezi). Marmara Üniversitesi, Eğitim Bilimleri Enstitüsü, İstanbul.

\section{EXTENDED ABSTRACT}

The children all over the world need protection and care in line with their development characteristics and periods. Today's children, which will constitute the keystones of a healthy society structure, will become the adults of tomorrow, and these children's physical, mental, social, moral and other development-related sides will be closely related to the respect, understanding, sensitivity and mindfulness to be shown by the societies in which they live towards their rights and law. The children have a number of special rights due to their development characteristics along with all other rights of all people. The child rights originate from the fact that both children are human being and they need care and protection. These rights can be defined as the benefits protected by law so that children can grow up in physical, mental, emotional and social respects (Karaman-Kepenekci, 2008). It is considered important to identify the attitudes of pre-service preschool teachers, preschool teachers and the parents with children enrolled in preschool education, the education shareholders involved in the preschool education directly, towards child rights and to compare their attitudes towards the child rights. A child receives his/her first education from his/her family and then pre-school education institutions, in which $\mathrm{s} /$ he is involved in formal education for the first time in accordance with the wish of his/her family. The goals of democracy education are fulfilled when children are allowed to learn and to use their rights in their families and schools, they are entitled to participate in decisions and works concerning them, and they are granted the ability to control their own behaviours. When considering that the students receiving education at preschool education institutions spend all their time at their homes and schools, it is necessary that firstly families, then preschool teachers and later on preservice preschool teachers should have required information on the children's rights, accordingly, they should involve in the education process by having sufficient awareness on the children's rights. All these will increase the quality of this process. The purpose of this research was to identify the attitudes of pre-service preschool teachers, preschool teachers and the parents with children enrolled in preschool education towards child rights and to reveal the difference, if any, between their attitudes related to child rights. This study was designed as a survey model based on quantitative research. The population of this study included all preschool teachers working at official educational institutions, preservice teachers receiving undergraduate education in the department of early childhood education at universities and the parents with children enrolled in preschool education institutions. In this regard, the sample of this research consisted of following subjects which were easy to reach by the researcher and who wanted to support the study voluntarily: 71 preschool teachers, working in the pre-school education institutions in the central districts of the province of Erzurum, a total of 97 pre-service preschool teachers whose 43 were receiving undergraduate education in the first-year class in the department of preschool teaching at Bayburt University and 54 of them were receiving undergraduate education in the first and year classes in the department of preschool teaching Tokat Gazi Osmanpasa University, and 245 parents, whose children were enrolled in pre-school education institutions in the provinces of Erzurum, Istanbul, Izmir, Ankara, Adana, Malatya and Erzincan. 
The "Demographic Information Collection Form" developed by the researcher and the "Attitude Scale for Children's Rights" developed by Karaman Kepenekci (2006) were used as data collection tools in this study. SPSS program was used for the statistical analysis of obtained data. In order to determine the types of analyses to be used in analysing obtained data, the analyses on whether the data obtained by the attitude scale for children's rights showed normal distribution were administrated. These analyses concluded that Skewness and Kurtosis values were out of -1.96 and +1.96 range. What is more, it was suggested that the data were not normally distributed as the result of the Kolmogorov-Smirnov test was found to be significant at $\mathrm{p}<0.05$ significance level. It is remarkable that most of the pre-service preschool teachers, preschool teachers and the parents were female according to the results of this study. In addition, it is also interesting that most of the parents in the sample of this study were female. The most significant situation was the fact that most of the parents with the children enrolled in preschool education had bachelor's degree. When this is considered in terms of the role and contributions of parents in education, it is hopeful in raising conscious generations. Another results of this study urged that there was a significant difference among the mean scores received by pre-service preschool teachers, preschool teachers and parents from the attitude scale for children's rights (CHTO). It was seen that this significant difference was caused by the groups between -service preschool teachers and parents. Followings may be suggested in line with the above results:

- In order to change the perception that preschool education level is a female-specific profession and area of responsibility by considering pre-service preschool teachers, preschool teachers and parents, these education shareholders may be given seminars and conferences that will create awareness related to pre-service courses, in-service courses and parent participation.

- This study was carried out on the sample group consisting of pre-service preschool teachers, preschool teachers and parents. Similar studies on different sample groups and different education levels may be conducted. 